\title{
Penyediaan Air Bersih Sistem Kolektif: Analisis Kebutuhan Air Bersih Domestik pada Perumahan Klaster
}

\author{
Wahyu Buana Putra', Nitih Indra Komala Dewi ${ }^{2}$, Tjahyani Busono ${ }^{2}$ \\ ${ }^{1}$ Program Studi Arsitektur, Fakultas Arsitektur dan Desain, \\ Institut Teknologi Nasional Bandung \\ ${ }^{2}$ Departemen Pendidikan Teknik Arsitektur, Fakultas Pendidikan Teknologi dan Kejuruan, \\ Universitas Pendidikan Indonesia, Bandung \\ Email: wbputra@itenas.ac.id ${ }^{1}$
}

\begin{abstract}
ABSTRAK
Air bersih merupakan kebutuhan dasar di lingkungan hunian. Penyediaan air bersih kota dikelola oleh Perusahaan Daerah Air Minum (PDAM). Akan tetapi tidak semua wilayah terjangkau dan terlewati jalur distribusi air minum kota. Pada perumahan sistem klaster yang berada di luar jalur distribusi air minum kota, suplai air bersih dan sistem distribusi yang efisien dan efektif menjadi tantangan tersendiri. Klaster perumahan The Sariwangi Village terletak di wilayah yang tidak terjangkau oleh pelayanan dari jaringan induk PDAM, oleh karena itu penyediaan air bersih disediakan oleh pengembang perumahan ini dan dikelola secara independen oleh warga. lingkungan ini mengandalkan sumber air tanah dalam dan mata air. Perumahan ini memiliki 100 kavling dengan 94 unit hunian sudah terbangun. Terdapat dua sistem penyediaan air yang diterapkan pada perumahan ini, 31 unit memiliki sumber air tanah secara mandiri melalui sumur bor yang dilengkapi dengan pompa hisap. Sedangkan sistem penyediaan air bersih pada 63 unit hunian menerapkan sistem kolektif dengan sistem tangki tekan. Distribusi air bersih dari tangki induk menuju setiap unit hunian dengan memanfaatkan gravitasi. Jaringan air bersih yang dibangun oleh pengembang, seringkali mengalami permasalahan terutama pada kecukupan debit air yang terdistribusi ke setiap hunian. Penelitian ini bertujuan untuk menganalisis kebutuhan air bersih dalam skala perumahan pada saat beban puncak. Berdasarkan hasil analisis dengan perkiraan jumlah penghuni 252 jiwa, perhitungan pemakaian kebutuhan air per hari 30.240 liter/ hari dengan pemakaian air pada jam puncak 4,86 m3/jam. Kecukupan kebutuhan air bersih per hari, diperlukan kapasitas efektif tangki atas sebesar 4,8 m3 dengan laju aliran pompa 81 liter per menit. Berdasarkan hasil analisis, diperlukan penambahan titik sumber air tanah dalam untuk memenuhi kebutuhan debit air bersih sistem kolektif.
\end{abstract}

Kata kunci: Sistem Tangki Tekan, Beban Puncak, Kapasitas Efektif Tangki, Kapasitas Pompa Pengisi.

\section{ABSTRACT}

Domestic water supply and distribution is a basic need in a residential environment. Water supply in the city is managed by the Regional Water Supply Company (PDAM). However, some areas are not covered by the city's water supply distribution channels. In cluster system housings outside urban water distribution channels, the efficiency of water supply and effective distribution systems is a challenge. The Sariwangi village housing cluster is located in an area unreachable by the PDAM pipeline installation, therefore the water supply is provided by this housing developer and managed independently by residents. There are two water supply systems implemented in this housing complex, 31 units have independent groundwater sources through boreholes equipped with suction pumps. Whereas the clean water supply system in 63 residential units applies a collective system of water supply with a pressure tank system. Distribution of clean water from the main tank to each residential unit by using gravity. The clean water network built by developers often experiences problems, especially in the adequacy of water discharges distributed to each dwelling. This study aims to analyze the need for clean water on a housing scale at peak times. The results of the analysis, the projected number of inhabitants is 252 occupants, the calculation of the use of water needs per day is 40,320 liters/day with an average usage of $4.03 \mathrm{~m} 3 /$ hour. Adequate need for clean water per day, an effective tank capacity of $5.4 \mathrm{~m} 3$ is required with a pump flow rate of $2.7 \mathrm{m3}$ per minute. Based on the results of the analysis improvements are needed to the addition of groundwater sources for a collective system clean water.

Keywords: Press Tank System, Peak Load, Effective Tank Capacity, Filling Pump Capacity. 


\section{PENDAHULUAN}

Pemenuhan kebutuhan air bersih di lingkungan hunian merupakan prioritas utama. Penyediaan air bersih di kota dikelola oleh Perusahaan Daerah Air Minum (PDAM) dengan memanfaatkan air baku. Air baku bersumber dari air tanah, air permukaan, air hujan, dan mata air. Pemanfaatan air tanah sebagai suplai air bersih terutama di daerah yang tidak terjangkau oleh pelayanan jaringan induk PDAM Kota. Akan tetapi, tidak semua daerah memiliki potensi air tanah yang layak. Potensi Air tanah di suatu wilayah dapat diketahui dari survei 10 buah sumur dapat mewakili potensi air tanah di wilayah tersebut dan berdasarkan informasi instansi yang terkait tentang jenis tanah/batuan, kualitas dan kuantitas air, dan kedalaman air tanah (Karya, 2007).

Pada perumahan yang berada di luar jalur distribusi air minum kota, suplai air bersih dan sistem distribusi yang efisien dan efektif menjadi tantangan tersendiri. Penyediaan air minum di lingkungan perumahan ini umumnya memanfaatkan air tanah dalam maupun sumber mata air yang berada di wilayah. Pada unit hunian di perumahan yang dibangun oleh pengembang, penyediaan air bersih direncanakan oleh pengembang. Terdapat dua sistem penyediaan air bersih yang direncanakan oleh pengembang, diantaranya: Pertama, suplai air bersih sistem mandiri, di masing-masing unit hunian dilengkapi dengan sumur bor dan disediakan unit pompa; Kedua, suplai air bersih sistem kolektif, yaitu penyediaan air bersih secara terpusat dan diperuntukkan beberapa unit hunian dengan menggunakan sistem distribusi jaringan perpipaan air bersih ke seluruh unit jaringan air bersih pada setiap unit hunian yang terhubung. Saat ini, sistem kedua banyak diterapkan oleh pengembang perumahan yaitu penyediaan air bersih pada perumahan sistem klaster yang dibangun dengan menggunakan sistem terpusat atau kolektif. Penyediaan air minum sistem kolektif disebut juga sebagai sistem perpipaan. Jaringan perpipaan adalah perpipaan transmisi yang berfungsi sebagai penyalur air bersih dari unit produksi menuju titik awal jaringan distribusi (Karya, 2007). Berdasarkan sistem pengalirannya, suplai air melalui jaringan distribusi pemipaan terdiri dari dua alternatif, antara lain: (1) Continuous System, yaitu sistem berkelanjutan yang mensuplai air kepada konsumen selama 24 jam; (2) Intermittent system, yaitu suplai dan distribusi air bersih dilakukan hanya selama beberapa jam dalam satu hari (Rivai et al., 2004).

Tujuan dari penyediaan air bersih sistem kolektif atau perpipaan berkaitan dengan faktor keamanan, kenyamanan dan kesehatan masyarakat. Oleh karena itu, standar air bersih yang disediakan harus memenuhi kelayakan dan persyaratan air minum. Persyaratan yang harus dipenuhi diantaranya syarat kualitas, syarat kuantitas serta syarat tekanan.

Persyaratan kualitas air bersih memenuhi syarat fisik, kimiawi, dan bakteriologi. Persyaratan secara fisik air bersih yang harus dipenuhi adalah kekeruhan, bau dan rasa, warna, dan temperatur. Air bersih dengan kualitas baik, dari segi fisik dapat terlihat melalui kejernihan air dan tidak berwarna, tidak berasa, tidak berbau, serta suhu air bersih memiliki suhu yang sama dengan suhu ruang dengan toleransi $\pm 3^{\circ} \mathrm{C}$. Pengolahan air baku bersumber dari air tanah dalam yang memiliki kandungan Besi (Fe) dan Mangan (Mn) di atas standar yang ditetapkan dalam batas layak konsumsi, maka diperlukan pengolahan terlebih dahulu melalui proses aerasi, filtrasi dan desinfektan untuk membunuh bakteri. Selanjutnya air baku didistribusikan ke masyarakat menjadi air bersih layak minum dengan memenuhi standar kelayakan air minum. Istilah air bersih selanjutnya oleh PDAM disebut sebagai air minum.

Persyaratan kuantitas air bersih berkaitan dengan kecukupan debit air yang harus tersedia untuk memenuhi kebutuhan domestik serta dapat digunakan setiap waktu. Kecukupan ketersediaan air bersih untuk kebutuhan rumah tangga harus berimbang dengan kesehatan karena pada dasarnya alasan kesehatan menjadi alasan utama pengembangan suatu sistem penyediaan air minum.

Persyaratan tekanan, berkaitan dengan pemerataan tekanan di dalam jaringan pipa distribusi. Tekanan di dalam jaringan pipa distribusi yang baik adalah tekanan yang cukup dan konstan, tidak boleh tinggi dan tidak boleh rendah. Apabila tekanan terlalu tinggi, maka dapat mengakibatkan rusaknya peralatan- 
peralatan plambing yang berfungsi sebagai distribusi air dan juga peralatan sanitair di dalam bangunan. Begitupun sebaliknya, apabila tekanan yang dihasilkan terlalu rendah, maka air di dalam jaringan pipa distribusi tidak dapat mengalir dengan baik terutama pada peralatan plambing di dalam bangunan. Standar tekanan air dalam jaringan pipa distribusi berkisar 10 - 40 meter kolom air (mka). Tekanan air pada jaringan pipa distribusi yang berada paling jauh dari tangki induk minimum 10 meter kolom air (mka). Tekanan minimum ini sudah mencukupi untuk menaikkan air ke alat plambing di lantai 2 (dua) bangunan. Apabila untuk lantai 3 (tiga) atau lebih harus dipompa lagi secara individu.

Ketiga persyaratan tersebut harus terpenuhi dalam jaringan distribusi air bersih, suplai air bersih yang tidak memenuhi kualitas air yang baik, kuantitas air yang tidak memadai, serta tekanan dalam pipa distribusi yang tidak memenuhi persyaratan maka akan menimbulkan masalah terutama pemenuhan kebutuhan air domestik di masing-masing unit hunian.

Perencanaan sistem distribusi air bersih pada komplek hunian yang didesain oleh pengembang menerapkan sistem kolektif. salah satunya pada komplek perumahan sistem klaster, The Sariwangi Village, terletak di daerah perbukitan dan termasuk ke dalam wilayah administratif Kabupaten Bandung Barat. Klaster perumahan The Sariwangi Village terletak di wilayah yang tidak terjangkau oleh pelayanan dari instalasi induk PDAM, sehingga penyediaan air bersih di lingkungan ini mengandalkan sumber air tanah dalam dan mata air.

Perumahan ini memiliki 100 kavling yang terdiri dari 94 unit hunian dan 6 kavling lahan siap bangun. Pengembang membuat lahan klaster ini dalam beberapa tahapan, tahap awal pengembang membangun unit-unit hunian dilengkapi dengan sumber air bersih mandiri (sumur mandiri), sedangkan tahap selanjutnya unit-unit hunian yang dibangun tidak dilengkapi dengan sumber air bersih mandiri melainkan menggunakan sumber air kolektif. Sehingga terdapat dua sistem penyediaan air yang diterapkan pada perumahan ini, sebanyak 31 unit memiliki sumber air tanah secara mandiri melalui sumur bor yang difasilitasi pompa tekan di tiap unit hunian dan 63 unit hunian di dalam komplek perumahan menggunakan sistem distribusi air kolektif atau perpipaan dengan sistem tangki atap. Distribusi air bersih dari tangki induk menuju setiap unit hunian dengan memanfaatkan gravitasi. Sistem ini digunakan apabila syarat topografi terpenuhi, berdasarkan perbedaan elevasi antara tangki induk dan tangki unit hunian yang dilayani. Sistem ini memiliki potensi energi yang cukup tinggi terhadap pelayanan unit hunian yang terjauh (Rivai,dkk., 2004).

Penyediaan air bersih yang menggunakan sistem kolektif mengalami beberapa permasalahan, terutama pada faktor kuantitas dan tekanan. Debit air kurang memadai dan kecukupan tekanan distribusi ke setiap hunian kurang memenuhi standar, sehingga unit hunian dengan sistem kolektif tidak memperoleh pasokan air yang memadai dikarenakan tekanan air pada jalur distribusi pusat kurang dan tidak mampu menaikkan air ke alat plambing di masing-masing unit hunian sekalipun yang satu lantai.

Dalam kasus yang lain, digambarkan bahwa sistem distribusi air yang tidak berfungsi dengan baik atau rancangan teknis tidak berjalan dengan baik, menyebabkan jangkauan wilayah dan berkaitan dengan waktu tidak memadai, maka dalam beberapa kasus menyebabkan dampak yang ekstrem terhadap faktor ekonomi, berkaitan dengan penggunaan air per kapita dan harga air volumetrik (Rooijen, 2008).

Tujuan tulisan ini adalah menganalisis sistem distribusi penyediaan air bersih di klaster perumahan yang menerapkan sistem kolektif dan mandiri dengan pengelolaan swadaya oleh warga. Diharapkan dari tulisan ini menghasilkan rekomendasi sistem distribusi air yang memenuhi standar dan persyaratan penyediaan air bersih.

\section{METODOLOGI}

\subsection{Lokasi dan Waktu Penelitian.}

Lokasi penelitian ini berada pada komplek perumahan The Sariwangi Village, Jl. Mekarwangi, Kabupaten Bandung Barat. Perumahan The Sariwangi Village memiliki 100 kavling, terdapat 94 unit 
hunian yang sudah terbangun dan 6 kavling lahan siap bangun. Hunian yang tersedia di klaster The Sariwangi Village terdapat berbagai macam berdasarkan luas rumah yang terbangun. Secara umum dapat dikelompokkan berdasarkan jumlah lantai dan jumlah kamar mandi atau toilet, yaitu (a) tipe hunian satu lantai dengan dua kamar dan satu kamar mandi; (b) hunian dua lantai dengan tiga kamar dan dua kamar mandi.

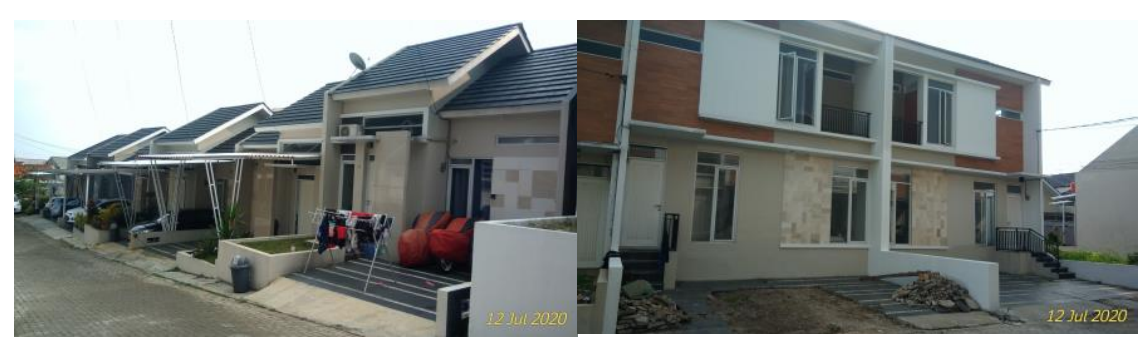

(a) (b)

Gambar 1. Tipe Hunian (a) satu lantai dengan 2 kamar dan 1 kamar mandi (b) dua lantai dengan 3 kamar dan 2 kamar mandi

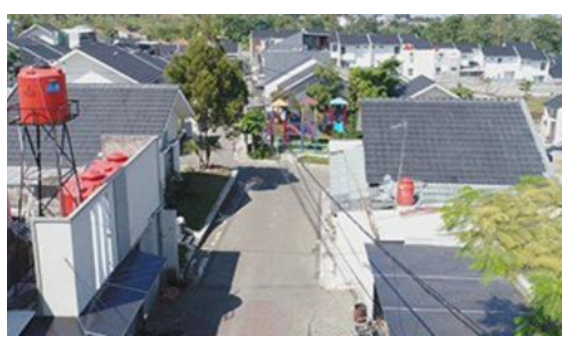

(a) View toren air kolektif dari atas

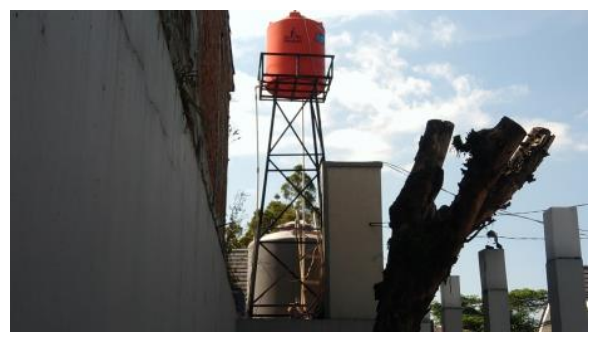

(b) View toren kolektif dari bawah

Gambar 2.2. Toren Kolektif The Sariwangi Village

Sumber : Arsip Pengurus IKSV, 2019

Toren atau tangki kolektif kluster The Sariwangi Village terdiri dari tiga tangki, yaitu : tangki A kapasitas 1000 liter, tangki B kapasitas 5000 liter dan tangki C kapasitas 5000 liter. Proses penelitian dilakukan pada bulan April 2020 sampai dengan Juni 2020, yang mana pada 3 bulan tersebut mulai diberlakukannya Work From Home atau bekerja dari rumah, sebagai dampak dari Pandemi COVID-19 yang sedang berlangsung.

\subsection{Metode Penelitian.}

Penelitian ini menggunakan metode kuantitatif deskriptif. Pendekatan studi kasus mengenai penyediaan air bersih di klaster perumahan digunakan dalam penelitian ini. Data diperoleh melalui observasi lapangan, pencatatan dan pengamatan langsung di lapangan, kemudian dikaji dan dianalisis berdasarkan studi pustaka. Hasil analisis dideskripsikan ke dalam pembahasan yang menghasilkan rekomendasi yang dapat dijadikan rujukan dalam peningkatan sistem penyediaan air bersih di lingkungan klaster perumahan.

Studi pustaka yang digunakan untuk menganalisa kebutuhan debit air adalah SNI 03-7065 (2005) tentang tata cara perencanaan plambing.

Perkiraan kebutuhan air dipengaruhi oleh :

- Pemakaian air per kebutuhan sehari (Qd $\mid \mathrm{m} 3^{3 /}$ hari)

- Pemakaian air rata-rata per jam $\left(\mathrm{Qh} \mid \mathrm{m}^{3} / \mathrm{jam}\right)$

- Pemakaian air pada jam puncak (Qh-max $\left.\mid \mathrm{m}^{3} / \mathrm{jam}\right)$

- Pemakaian air pada menit puncak (Qm-max $\mid \mathrm{m}^{3} /$ menit ) 
Tabel 1. Pemakaian air dingin minum sesuai penggunaan gedung

\begin{tabular}{llll}
\hline \multirow{2}{*}{ No. } & \multicolumn{1}{c}{ Penggunaan Gedung } & $\begin{array}{c}\text { Pemakaian } \\
\text { Air }\end{array}$ & Satuan \\
\hline 1 & Rumah Tinggal & 120 & Liter/ penghuni/ hari \\
\hline 2 & Rumah susun & 100 & Liter/ penghuni/ hari \\
\hline 3 & Asrama & 120 & Liter/ penghuni/ hari \\
\hline 4 & Rumah Sakit & 500 & Liter/ tempat tidur pasien/ hari \\
\hline 5 & Sekolah Dasar & 40 & Liter/ siswa/ hari \\
\hline 6 & SLTP & 50 & Liter/ siswa/ hari \\
\hline 7 & SMU/ SMK dan lebih tinggi & 80 & Liter/ siswa/ hari \\
\hline 8 & Ruko/ Rukan & 100 & Liter/ penghuni dan pegawai/ hari \\
\hline 9 & Kantor/ Pabrik & 50 & Liter/ pegawai/ hari \\
\hline 10 & Toserba, toko pengecer & 5 & Liter/ m 2 \\
\hline 11 & Restoran & 15 & Liter/ kursi \\
\hline 12 & Hotel berbintang & 250 & Liter/ tempat tidur/ hari \\
\hline 13 & Hotel Melati/ penginapan & 150 & Liter/ tempat tidur/ hari \\
\hline 14 & Gd. Pertunjukan, bioskop & 10 & Liter/ kursi \\
\hline 15 & Gd. Serba Guna & 25 & Liter/ kursi \\
\hline 16 & Stasiun, terminal & 3 & Liter/ penumpang tiba dan pergi \\
\hline 17 & Peribadatan & 5 & Liter/ orang (belum termasuk air wudhu)
\end{tabular}

Sumber : SNI 03-7065 tahun 2005

Menurut Morimura, langkah-langkah perhitungan kebutuhan air bersih dalam gedung antara lain: (1) Pemakaian air dalam satu hari, (2) Kebutuhan rata-rata pemakaian per hari, (3) Pemakaian air pada jam puncak, (4) Pemakaian air pada menit puncak (Suhardiyanto, 2016).

Roof tank merupakan reservoir yang dipergunakan untuk melayani fluktuasi kebutuhan air minum pada saat-saat tertentu. Perhitungan volume tangki atap (roof tank) untuk air bersih kelas satu menggunakan rumus :

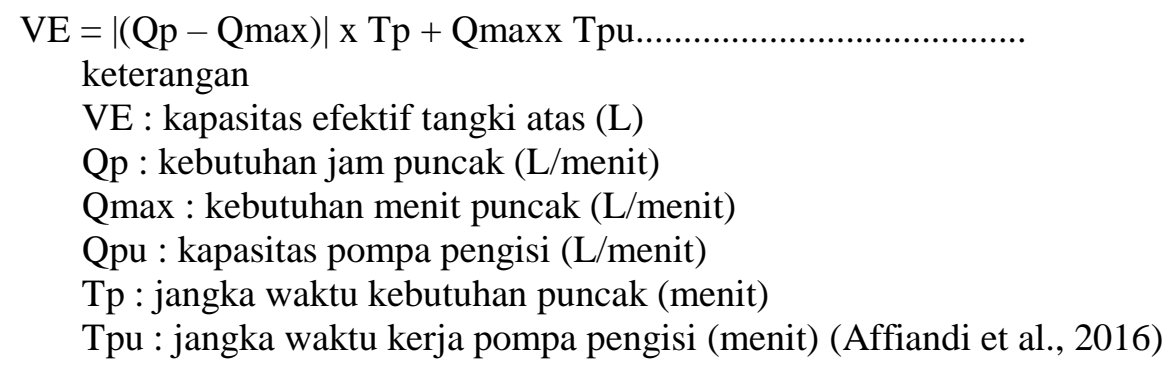

\section{HASIL DAN PEMBAHASAN}

\subsection{Sumber Air}

Sumber air yang digunakan pada perumahan The Sariwangi Village adalah air sumur pompa dengan kedalaman kurang lebih $58 \mathrm{~m}$ dan diameter sumur 4 inch. Air sumur tersebut dihisap menggunakan pompa hisap submersible dengan spesifikasi daya hisap $5 \mathrm{~m}^{3} / \mathrm{jam}$, yang kemudian disalurkan ketiga tangki atap.

Gambar 3.1 memperlihatkan bahwa pipa input sumber air dari pompa sumur dalam berdiameter 1 inch, masuk ke toren B berukuran 5.000 liter, kemudian disedot menggunakan pompa untuk mengisi toren A yang lebih tinggi dengan kapasitas 1.000 liter. Dua toren dengan kapasitas masing-masing 5.000 liter (toren B dan C) saling terhubung satu sama lain, sehingga kedua toren ini akan terisi dalam waktu yang bersamaan. Toren A digunakan untuk mensuplai air bersih kepada dua belas hunian, dengan pipa distribusi berdiameter 1 inch, sedangkan pipa keluar toren $\mathrm{B}$ dan $\mathrm{C}$ berdiameter 2 inch yang saling terhubung, kemudian mengecil menjadi diameter 1 inch dan dipecah kedalam dua jalur utama, yaitu jalur B untuk mensuplai 28 hunian dan jalur C untuk mensuplai 23 hunian. Perumahan The Sariwangi 
Village merupakan perumahan baru dan didominasi oleh keluarga muda dengan jumlah anggota minimum dalam satu keluarga yaitu 4 penghuni. Sehingga kapasitas tangki ideal per hunian adalah 480 liter untuk memenuhi kebutuhan air dalam satu hari dengan satu kali periode pengisian tangki.

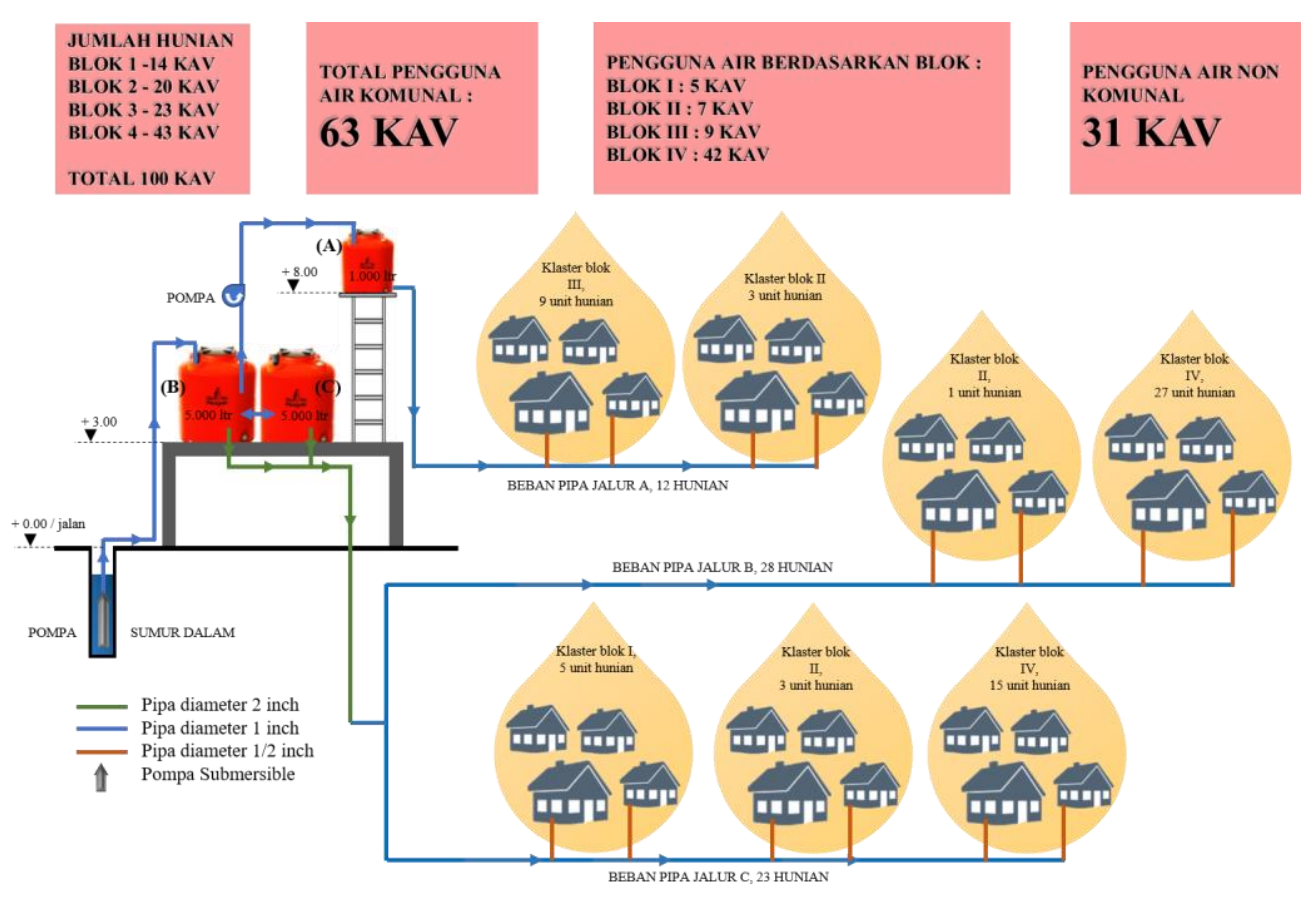

Gambar 3.1. Peta Jaringan Distribusi Air Bersih

Sumber : Arsip Pengurus IKSV, 2019

Proyeksi kebutuhan air bersih ditentukan oleh beberapa parameter, antara lain: (1) cakupan pelayanan, yaitu persentase penduduk yang dilayani; (2) Persentase dari jumlah keluarga yang dilayani sambungan rumah; (3) Persentase keluarga yang dilayani oleh sambungan kran umum (perbandingan antar sambungan rumah dan kran umum); (4) Kebutuhan air per jiwa per hari untuk rumah tangga (baik sambungan rumah, maupun sambungan dengan kran umum); (5) Jumlah kebutuhan air per hari untuk non-rumah (non-domestik); (6) Jumlah kebutuhan air yang hilang (tidak tercatat); (7) fluktuasi pemakaian air.

Fluktuasi pemakaian air bersih dipengaruhi oleh faktor-faktor, antara lain: (1) Pola wilayah; (2) Kegiatan penduduk; (3) Jumlah penduduk; (4) Adat kebiasaan penduduk. Faktor pemakaian jam puncak dipengaruhi oleh (1) Besarnya populasi; (2) Pemakaian puncak lebih besar pada komunitas kecil daripada komunitas besar. Berdasarkan statistik, kemungkinan pemakaian yang bersamaan pada waktu tertentu, persentasenya besar pada populasi kecil.

\subsection{Pengukuran kapasitas pompa pengisi eksisting}

Hasil pengamatan di lapangan untuk mengisi tangki 11.000 liter dari kosong hingga penuh, membutuhkan waktu kurang lebih $3 \mathrm{jam}$, hal ini disebabkan katup stop kran pada pompa submersible hanya dibuka sebagian. Jika katup stop keran pada pompa submersible dibuka penuh, maka akan menyebabkan kekosongan air pada sumur pompa, hal ini mengindikasikan bawah debit air tanah di sumur tidak mencukupi, sedangkan daya/kapasitas hisap dari pompa besar yaitu $5 \mathrm{~m}^{3} / \mathrm{jam}$ atau 83,33 liter/menit. Berdasarkan waktu pengisian tangki induk 11.000 liter yang membutuhkan waktu 3 jam atau sama dengan 61,11 liter/menit atau $0,061 \mathrm{~m}^{3} /$ menit. (lihat tabel 3.1) 


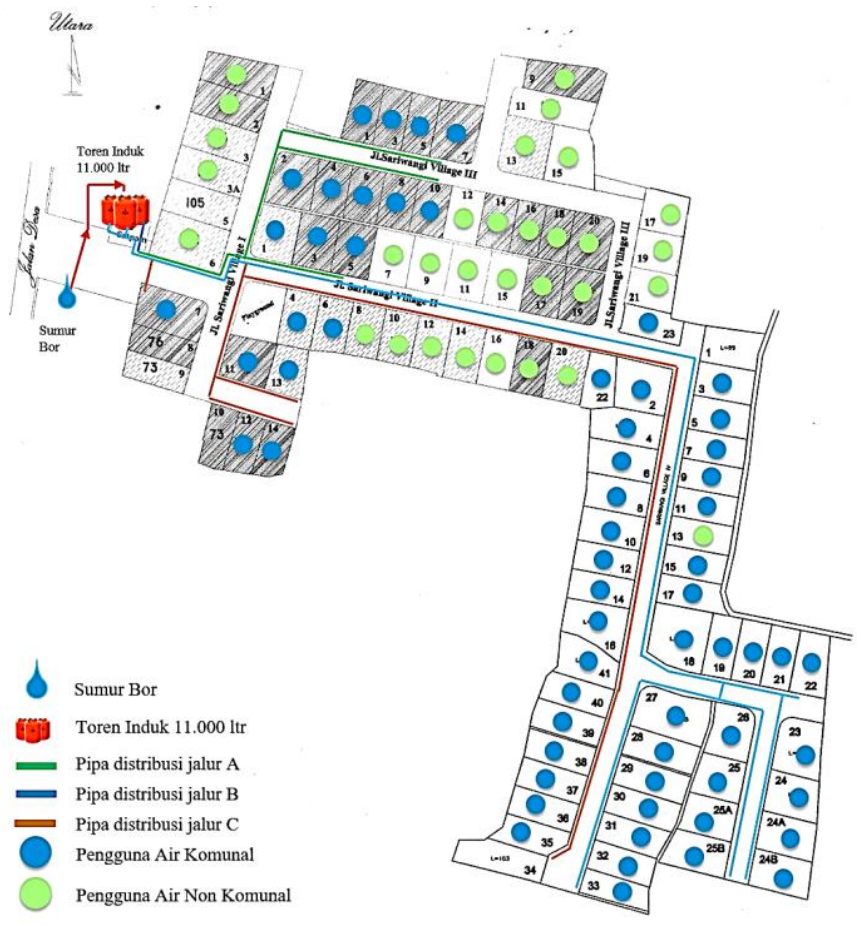

Gambar 3.2. Peta Jaringan Distribusi Air Bersih Sumber : Arsip Pengurus IKSV, 2019

Tabel 3.1: Perbandingan kondisi ideal dengan kondisi dilapangan

\begin{tabular}{lccc} 
Parameter & Ideal & $\begin{array}{c}\text { Kondisi } \\
\text { dilapangan }\end{array}$ & Satuan \\
\hline Daya/ kapasitas pompa pengisi & 83,33 & 61,11 & liter/menit \\
\hline Waktu pengisian & 2,2 & 3 & jam \\
\hline
\end{tabular}

\subsection{Analisis kebutuhan kapasitas air}

Pemenuhan kebutuhan air bersih dipengaruhi tiga faktor, antara lain penduduk yang dilayani, kebutuhan air bersih domestik/ rumah tangga, dan jumlah pemakaian air. (Torumuda, 2017)

Analisis kebutuhan debit air diawali dengan perhitungan perkiraan kebutuhan air dalam sehari berdasarkan jumlah penuhi. Perumahan The Sariwangi Village merupakan perumahan baru dan didominasi oleh keluarga muda sehingga perkiraan jumlah penghuni pengguna air sistem kolektif pada 63 hunian dikali dengan jumlah anggota minimum dalam satu keluarga yaitu 4 penghuni. Sehingga diperkirakan jumlah minimum penghuni perumahan adalah 252 orang pengguna air sistem kolektif. Tujuan utama perkiraan kebutuhan ini untuk memperoleh jumlah pemakaian air dalam sehari, pemakaian air rata-rata dalam satu jam, pemakaian air pada jam puncak dan pemakaian air pada menit puncak.

$\begin{array}{lll}\text { Qd } & \text { Pemakaian air dalam sehari } & \mathrm{m}^{3 / h a r i} \\ \text { Qh } & \text { Pemakaian air dalam satu jam } & \mathrm{m}^{3 / \mathrm{jam}} \\ \text { Qh-max } & \text { Pemakaian air pada jam puncak } & \mathrm{m}^{3} / \mathrm{jam} \\ \text { Qm-max } & \text { Pemakaian air pada menit puncak } & \mathrm{m}^{3} / \mathrm{menit} \\ \text { T } & \text { Jangka waktu pemakaian sehari } & \text { jam } \\ \text { c1 } & \text { Konstanta antara } 1,5-2,0 & \\ \text { c2 } & \text { Konstanta antara } 3-4 & \end{array}$

Berdasarkan SNI 03-7065 (2005) bahwa konsumsi air bersih untuk rumah tinggal biasa adalah 120 liter/orang/hari. Sehingga perhitungan kebutuhan air untuk klaster perumahan The Sariwangi Village, sebagai berikut: 
Konsumsi air bersih

Jumlah penghuni yang dilayani

Durasi Pemakaian air bersih rumah tinggal

$\mathrm{Qd}=$ Konsumsi air $\mathrm{x}$ jumlah penghuni

$\mathrm{Qh}=\mathrm{Qd} / \mathrm{T}$
63 unit hunian $\mathrm{x} 4$ orang
(T)

120 liter $\mathrm{x} 252$ orang $30.240 \mathrm{~m} 3 / 10 \mathrm{jam}$
$=120$ liter/ hari

$=252$ orang

$=\quad 10 \mathrm{jam}$

$=30.240$ liter/ hari

$=\quad 3,24 \mathrm{~m}^{3} / \mathrm{jam}$

$=\quad 4,86 \mathrm{~m}^{3} / \mathrm{jam}$

$=0,16 \mathrm{~m}^{3} /$ menit

Pemakaian air pada jam puncak dengan konstanta $\mathrm{c} 1=1,5$

$1,5 \times 3,24$

Pemakaian air pada menit puncak dengan konstanta $\mathrm{c} 2=3,0$

$\mathrm{Qm}-\mathrm{max}=\mathrm{c} 2 \times(\mathrm{Qh} / 60)$

Hasil perhitungan diatas sudah termasuk aktivitas rumah tangga penghuni, namun belum termasuk kebutuhan air yang diperlukan pengelolaan bangunan, siram tanaman, membersihkan bangunan, kolam, hidran yang harus diperhitungkan secara terpisah.

Menghitung kapasitas tangki atas bertujuan untuk memenuhi kebutuhan puncak dengan durasi 30 menit (Tp). Durasi 30 menit pada berbagai kasus merupakan jangka waktu yang cukup untuk memenuhi beban puncak. Namun pada kondisi tertentu, awal dari kebutuhan air puncak dimulai pada saat muka air didalam tangki pada posisi terendah, namun debitnya belum habis. Saat air pada posisi terendah, pengisian tangki harus dilakukan dengan durasi yang lebih cepat dari durasi kebutuhan puncak. Sehingga durasi pengisian tangki ditetapkan selama 10 - 15 menit (Tpu) namun hal ini lebih dipengaruhi oleh jumlah dan kapasitas pompa (Qpu).

$\begin{array}{lll}\text { Ve } & \text { : Kapasitas efektif tangki atas } & \text { liter } \\ \text { Qp } & \text { : Laju aliran penyediaan pada kebutuhan puncak } & \text { liter/menit } \\ \text { Qmax } & \text { : Laju aliran pemakaian pada jam puncak } & \text { liter/menit } \\ \text { Qpu } & \text { : Kapasitas pompa pengisi } & \text { liter/menit } \\ \text { Tp } & \text { : Jangka waktu pemakaian puncak } & \text { menit } \\ \text { Tpu } & \text { : Jangka waktu kerja pompa pengisi } & \text { menit }\end{array}$

$$
\text { Ve }=(Q p-Q m a x) T p+(Q p u x T p u)
$$

Nilai Ve akan efektif jika laju aliran pompa pengisi (Qpu) sama besar dengan laju aliran pemakaian pada jam puncak (Qmax).

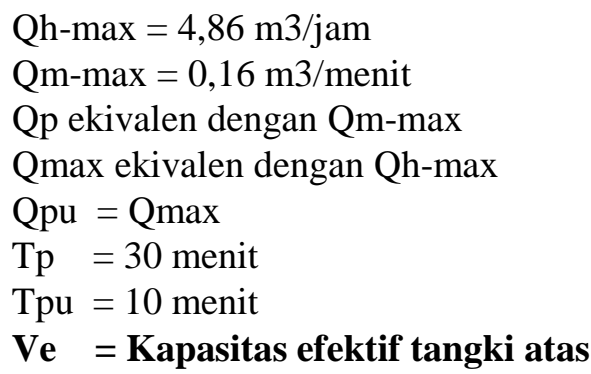

$$
\begin{gathered}
4,86 \times 1000 / 60 \\
0,16 \times 1000
\end{gathered}
$$

$$
\begin{array}{rr}
= & 81 \mathrm{liter} / \text { menit } \\
= & 160 \mathrm{liter} / \mathrm{menit} \\
= & 160 \mathrm{liter} / \mathrm{menit} \\
= & 81 \mathrm{liter} / \mathrm{menit} \\
= & 81 \mathrm{liter} / \mathrm{menit}
\end{array}
$$

$$
(160-81) 30+(81 \times 30)=\quad 4.800 \text { liter }
$$

Hasil perhitungan diatas dapat ditarik kesimpulan, bahwa kapasitas tangki efektif adalah 4800 liter dengan menggunakan pompa yang memiliki daya pengisian 81 liter/ menit dan dilengkapi dengan tangki bawah paling sedikit mampu memenuhi kebutuhan air sejumlah 30.240 liter/hari. Namun pada instalasi air kolektif perumahan The Sariwangi Village tidak dilengkapi dengan tangki penampungan air bawah, sehingga harus dilakukan pemeriksaan lebih lanjut debit air yang tersedia disumur pompa. 
Tabel 3.2 : Perbandingan kondisi eksisting dengan hasil analisis

\begin{tabular}{llccr}
\hline & Parameter & Kondisi Eksisting & Hasil Analisis & Satuan \\
\hline & Kapasitas tangki bawah kolektif & tidak ada & 30.240 & liter/ hari \\
\hline $\mathrm{Ve}$ & Kapasitas tangki atas kolektif & 11.000 & 4800 & liter \\
\hline & Kapasitas tangki individu 63 unit & 15.750 & tidak ada & liter \\
\hline Qpu & Kapasitas pompa pengisi & 83.33 & 81 & liter/menit \\
\hline
\end{tabular}

Perbandingan diatas menunjukkan bahwa untuk kapasitas pompa eksisting sudah sesuai, namun kondisi eksisting tidak terdapat tangki bawah kolektif. Hal ini menyebabkan sumur pompa berganti peran sebagai tangki bawah kolektif, namun hasil observasi dilapangan debit air sumur pompa tidak mampu mengimbangi kecepatan kapasitas pompa pengisi, sehingga menyebabkan air didalam sumur selalu habis dalam waktu singkat dan kebutuhan debit air sejumlah 4,86 m3/jam pada jam puncak tidak terpenuhi.

\section{SIMPULAN}

Berdasarkan hasil analisis diatas dapat disimpulkan bahwa tangki atas kolektif dapat berperan berfungsi optimal jika debit air yang berada pada sumur pompa mencukupi. Adapun solusi untuk mengatasi debit air yang tidak mencukupi pada jam puncak adalah (a) membuat tangki bawah kolektif dengan kapasitas minimal sejumlah kebutuhan air harian, (b) membuat sumur pompa baru sebagai tambahan debit air agar mencukupi kebutuhan pada jam puncak. Diperlukan penelitian lebih lanjut terkait besar diameter ideal pipa distribusi dari tangki atas kolektif menuju unit-unit hunian agar diperoleh besar tekanan air yang ideal disetiap hunian.

\section{UCAPAN TERIMA KASIH}

Penulis ucapkan terima kasih yang mendalam kepada seluruh pengurus Ikatan Keluarga Sariwangi Village yang telah membantu dalam proses penelitian ini dan semua pihak yang tidak dapat penulis sampaikan satu persatu.

\section{DAFTAR PUSTAKA}

[1] Affiandi, J., Pharmawati, K., D., \& Nurprabowo, A. (2016). Perencanaan Sistem Instalasi Plambing Air Bersih Gedung Hotel Tebu. Jurnal Online Institut Teknologi Nasional, 4(2), 1-9. https://ejurnal.itenas.ac.id/index.php/lingkungan/article/view/1047

[2] Karya, C. (2007). Petunjuk Teknis Pelaksanaan Prasarana Air Minum Sederhana ini. http://ciptakarya.pu.go.id/dok/hukum/pedoman/juknis_pelaksanaan_prasarana_air_minum_seder hana.pdf

[3] Rivai, Y., Masduki, A., \& Marsono, B. D. (2004). Evaluasi sistem distribusi dan rencana peningkatan pelayanan air bersih pdam kota gorontalo. SmartEk, 126-134.

[4] Rooijen, D. J. Van. (2008). Domestic water supply in Accra : how physical and social constraints to planning have greater consequences for the poor . Domestic water supply in Accra: How physical and social constraints to planning have greater consequences for the poor. WEDC International Conference, 33rd.

[5] Suhardiyanto. (2016). Perancangan Sistem Plambing Instalasi Air Bersih Dan Air. Teknik Mesin, 05(3), 90-97.

[6] Torumuda, R. (2017). Analisa Sistem Pemipaan Penyediaan Air Bersih Pada Kecamatan Medan Sunggal Kota Medan Dan Kebutuhannya Pada Tahun 2064. Jurnal Teknik Sipil Usu, Vol 6(No 1), 1-13. https://jurnal.usu.ac.id/index.php/jts/article/view/19387

[7] SNI 03-6481-2000. (2000). Sistem Plambing. Jakarta: BSN

[8] SNI 03-7065-2005. (2005). Tata Cara Perencanaan Sistem Plambing. Jakarta: BSN 